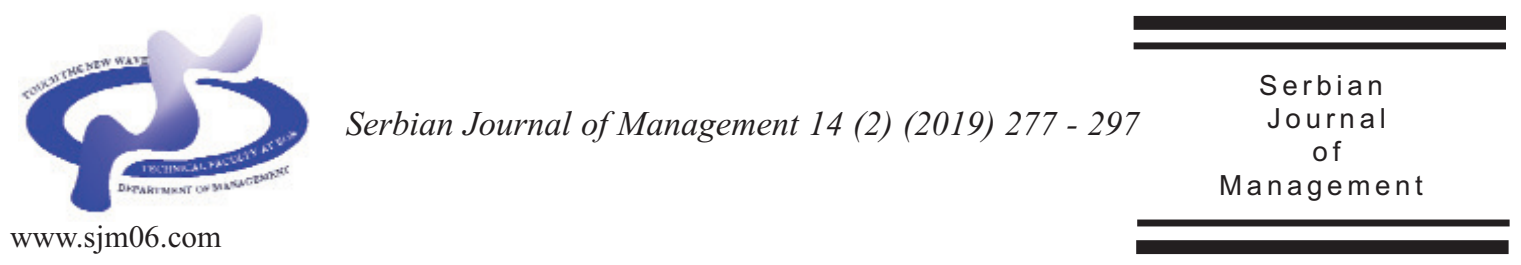

\title{
EXTENSION OF THE SYSTEMIC ENTREPRENEURSHIP INTENTION MODEL IN UNIVERSITY STUDENTS
}

\author{
Luisa Díez-Echavarría ${ }^{a}$, Alejandro Valencia Arias ${ }^{a}$, Jonathan Bermúdez- \\ Hernández $^{a}$, Fausto Orlando Maussa Pérez ${ }^{b}$, Maria Lucelly Urrego Marínc and \\ Jairo Adolfo Torres Velásquez \\ a Instituto Tecnológico Metropolitano, Calle 54 A 30 01, Parque I, \\ Sciences Administratives Lab, Medellín, Antioquia, Colombia \\ ${ }^{b}$ Universidad de Medellín, Carrera $87 N^{\circ} 30$ - 65, Medellín, Antioquia, Colombia \\ ${ }^{c}$ Corporación Universitaria Minuto de Dios, Carrera 45, Bello, Antioquia, Colombia
}

(Received 04 May 2018; accepted 08 February 2019)

\begin{abstract}
The extension of the Systemic Entrepreneurship Intention Model, to identify and understand the factors, and their relations, that promote university students' entrepreneurial intention, was proposed in this paper. That is, in the long run, one of the main strategies to promote economic development. The Confirmatory Factor Analysis methodology to analyze the data collected from a selfadministrative questionnaire, which was applied to students of three universities of Colombia, was performed. It was found that personal attitudes and perceived feasibility are the most influential factors when it comes to starting a business. Moreover, young people may have greater intentions of creating a company when they identify good ideas and they perceive them feasible regardless of their risk levels. It is recommended implementing this model in the context of university students in emerging economies to obtain reliable results in understanding their behavior.
\end{abstract}

Keywords: entrepreneurial intention, higher education, student population, Theory of Planned Behavior.

\section{INTRODUCTION}

The biggest interest in research regarding entrepreneurial intention comes from the student population (Ferreira et al., 2012; Montoya et al., 2016), mainly because of the youth unemployment and entrepreneurial potential. In one hand, youth unemployment is a big problem in our society because it hinders the formation and training of the new human capital needed to generate wealth in their regions (Awogbenle \& Iwuamadi,

* Corresponding author: luisadiez@itm.edu.co

DOI: $10.5937 /$ sjm14-17336 
2010; Quiroga-Juárez \& VillalobosEscobedo, 2015), and when it is long-lasting, it becomes a powerful source of inequality (Machin \& Manning, 1998). This situation happens when enterprises do not hire young people because of their lack of experience in the different fields of action, population growth, social policies as specific mandatory salaries, and generally speaking, young people undergo more than older adults ( Hess et al., 2006; Hernández-López et al., 2018).

On the other hand, this is the population group that has the highest probabilities of becoming potential entrepreneurs (Olsen, 2013; Ortiz-Delgadillo et al., 2017) because this stage of university life is the stage that defines their short and middle term future perspectives offering them different possibilities after graduation which will vary depending on their characteristics (Hong et al., 2012).

To mitigate youth unemployment and to take advantage of the entrepreneurial potential, higher education institutions must teach their students to develop competencies and skills to face these problems ( Setiawan, 2012; Fayolle \& Gailly, 2015; Valencia et al., 2015), so that they do not have to go out and look for a job but create one instead ( $\mathrm{Ng}$ et al., 2014; Kautonen et al., 2015a), and thus contribute to economic growth (Ghazali et al., 2012). Therefore, there is a need to focus research on entrepreneurship for sub representative groups or those having the highest obstacles to create enterprises like young people (Mohamed et al., 2012; Dinis et al., 2013; Kautonen et al., 2015b;).

As the entrepreneurship is a complex phenomenon (Benyamin, 2016), modeling is a good way to analyze and better understand this behavior and all the elements involved. Although the existing models (described in the next section) manage to capture relations between few constructs and entrepreneurial intention, it is necessary to identify other related factors and validate it in university contexts. Then, it is important to know what factors influence the entrepreneur intention in university students, and how these factors interact?

This study presents a variation of the Systemic Entrepreneurship Intention Model (Valencia et al., 2012) and aims at expanding the comprehension of the complex phenomenon of entrepreneurial intention among young people, more specifically at the university level. This objective is achieved through the model's illustrative capacity and the identification of the variables involved in an entrepreneurial intention training process that facilitates a strategy design focused on improving pedagogic processes in entrepreneurship teaching. The first step involves proposing a theoretical framework followed by a methodology; finally, we present the findings and some relevant conclusions of the study.

\section{THEORETICAL BACKGROUND}

\subsection{Entrepreneurial intention assessment models}

In studies on entrepreneurship-related topics, one of the main theories is the Theory of Planned Behavior (TPB) (Ajzen, 1991), which explains that the best way to determine if an individual will act in a certain way is to study their intention (Hattab, 2014; Van Gelderen et al., 2015). The Theory of Planned Behavior seeks to explain people's behavior based on relations such as beliefs-attitudes and intentionbehavior. It constitutes the extension of the 
theory of reasoned action (Ajzen \& Fishbein, 1980) focused on those behaviors individuals are not in total control of but are instead conditioned to a certain extent by nonmotivational factors related to the availability of certain requirements and resources (Sampedro et al., 2013).

It appears that intentions to perform different types of behaviors can be predicted very accurately based on specific attitudes towards certain behaviors, subjective norms, and perceived behavioral control. Furthermore, these intentions along with the perception of behavioral control represent a considerable variation of the real behavior (Ajzen, 1991; Marulanda et al., 2014). Intentions, subjective norms and perceived behavioral control are related to sets of behaviors, regulations, and beliefs regarding behavioral control (Ajzen, 1991). It seems that people with similar traits or constructs show similar entrepreneurship-related behaviors (Botsaris \& Vamvaka, 2012; Valencia \& Benjumea, 2013).

Thus, models based on intentions rely on constructs that are very good at predicting and explaining entrepreneurial behavior (Botsaris \& Vamvaka, 2012), so they have been vastly used since the early 90 s, which proves their importance and applicability in various contexts (Liñán \& Fayolle, 2015).

Later, Segal et al. (2005) proposed an adaptation of the TPB applied to entrepreneurship, enabling the creation of The Entrepreneurial Intention Model (EIM), which is a resource for the construction of the Systemic Entrepreneurship Intention Model (SEIM) proposed by Valencia et al. (2012), who proved the existence of twoway relations like the ones described in Figure 1.

The model of this study is based on this systemic entrepreneurial intention model, in which there are three factors that explain entrepreneurial intention. A factor known as perceived convenience is defined as the attractiveness of starting a business. The feasibility factor could be explained as the degree to which an individual feels capable of doing something and his determination to follow his own decisions (Lee et al., 2011), and the risk tolerance factor denotes an

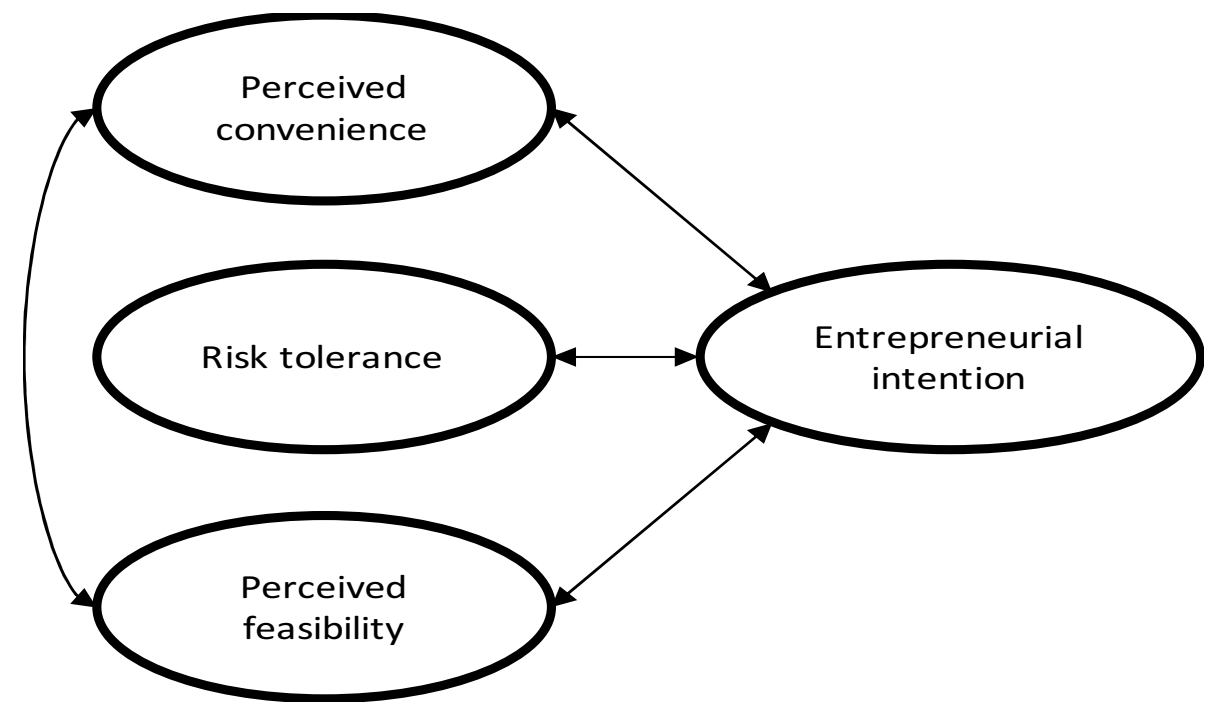

Figure 1. Systemic Entrepreneurship Intention Model - SEIM 
"individual's willingness to accept a calculated risk" (Segal et al., 2005).

Although this model has been validated, lacks two important variables identified by (Ajzen, 1991; Erikson, 2002; Naktiyok et al., 2009): entrepreneurial behavior and personal attitudes. It is necessary to validate if five factors are explaining the entrepreneurial intention in the context of university students.

\subsection{Importance of the study on intention}

The idea of starting a business depends on the entrepreneur's academic background (Nasiru et al., 2015), personality (Murugesan \& Dominic, 2013), surrounding models (Obschonka et al., 2012) and the opportunities available in his particular context (Audet, 2004), so all these items are essential for an individual to exhibit a particular intention (Valencia-Arias et al., 2017).

Intentions are good indicators of a particular action, in this case starting an enterprise (Devonish et al., 2010). However, they are sometimes uncertain because entrepreneurial perceptions and intentions evolve in time (Liñán et al., 2011), and because of the emerging trends that develop from the moment the intention to create a company consolidates to the moment a potential entrepreneur starts the company (Cassar, 2007).

Intention refers to goals and future actions (Lortie \& Castogiovanni, 2015), and there is no conflict between intention and a lack of action, in case that it is proposed deliberately, new restrictions arise or preferences change (Van Gelderen et al., 2015). Nevertheless, an individual who has an entrepreneurial intention is expected to carry out specific actions (Kautonen et al., 2015a), and to do so, it is crucial to understand the factors that affect entrepreneurial intentions.

Therefore, it is necessary to continue implementing entrepreneurial intention models within university contexts as they allow identifying those factors and enable an adequate strategy approach to factors with the highest impact (Küttim et al., 2014). This is achieved by bearing in mind that the social and cultural surroundings of this population, as well as their beliefs, values and attitudes, influence their behavior and their decisions, which led us to the finding that university students' entrepreneurial intentions are affected by the perception of convenience and the feasibility of creating a new enterprise (Díaz-Casero et al., 2012; Echeverri-Sánchez et al., 2018).

Moreover, it is essential to consider investments in human capital from active university students, including time and money invested in courses related to entrepreneurial initiatives, which represent the capitalization of the knowledge and the skills to create enterprises. This knowledge and skills will make the student population more comfortable to take different risks in creating enterprises when students enroll (Martin et al., 2013).

The above goes along with what Naktiyok et al. (2010) have proposed. They found that university students have a high degree of tolerance to ambiguity because this type of population is enthusiastic when faced to uncertainty and the unknown. They are prone to experimenting and engaging in new challenges which resembles the cases in which enterprises are created with an innovative component. Furthermore, the more creative and innovative capabilities students have, the higher their possibilities to 
perceive things in the light of new entrepreneurial ideas about other population groups (Naktiyok et al., 2010; Cadavid et al., 2017).

\section{METHODOLOGY}

\subsection{Proposed model}

For this study, a new model based on EIM constructs is proposed. To provide more accuracy and detail, useful to understand the entrepreneurship phenomenon, the model includes additional constructs. The following hypotheses are taken from the above model:

Initially, perceived convenience is defined as the attractive to start a business, which subordinates the intention of undertaking because it is directly related with the believing that one has to get good results being an entrepreneur ( Lee et al., 2011; Echeverri et al., 2012).

H1: Perceived convenience influences entrepreneurial intention.

$\mathrm{H} 2$ : Entrepreneurial intention influences perceived convenience.

Besides, the risk tolerance is positively associated with the self-employment intentions through of its influence on certain predictors of them, like self-effectiveness and positive attitude toward entrepreneurial behavior (Zhao et al., 2005).

H3: Risk tolerance influences entrepreneurial intention.

H4: Entrepreneurial intention influences risk tolerance.

Also, it has been shown the capacity that perceived viability has to predict entrepreneurial intention, both directly and indirectly, evidencing to perceived viability; there are greater proactivity and greater attraction for creating a company (Sánchez et al., 2005).

H5: Perceived feasibility influences entrepreneurial intention.

H6: Entrepreneurial intention influences perceived feasibility.

Likewise, it has been observed the relationship between perceived convenience and perceived viability (Díaz-Casero et al., 2012), related with the belief that being entrepreneur leads greater benefits than work for others (Segal et al., 2005).

H7: Perceived convenience influences perceived feasibility.

H8: Perceived feasibility influences perceived convenience.

This study involves including two additional constructs to the model allowing to better explain university students' entrepreneurial intention: entrepreneurial behavior and personal attitudes. Entrepreneurial behavior can be explained as a search for opportunities and their products with no regard for the resources which are currently controlled (Erikson, 2002; Naktiyok et al., 2009). Personal attitudes is one of the most frequently studied entrepreneurship-related variables (Sánchez, 2010) and can be explained as " a predisposition to respond favorably or unfavorably when referring to a given object," in other words, it is the perception of the attractiveness of behavior (Ajzen, 1991). Thus, the following hypotheses are presented:

Van Dam et al. (2010) affirm such behavior implies resources management to take advantage of recognized opportunities so that those experiences and past behaviors make an influence in perceived convenience to create a company.

H9: Entrepreneurial behavior influences perceived convenience.

H10: Perceived convenience influences 
entrepreneurial behavior.

Additionally, for Armitage \& Conner, (2001) and Kautonen et al. (2013), the behavior is a factor that influences entrepreneurial intention, being TCP the one that best describes it. Besides, intentions capture motivational factors that influence in behavior since they are indicators of how strong the person who try, that is, how much effort it is planning to execute to achieve the desired behavior (factors that influence intention). As a general rule, the stronger the intention, the more likely it is to execute the behavior (Ajzen, 1991).

H11: Entrepreneurial behavior influences entrepreneurial intention.

H12: Entrepreneurial intention influences entrepreneurial behavior.

Likewise, perceived viability can be motivated by different personal aspirations and motivations such as innovation, independence and financial success, which are part of an entrepreneurial behavior, where in turn can generate different types of entrepreneurs who will form companies to replace their income or to develop them (Carey et al., 2010).

H13: Entrepreneurial behavior influences perceived feasibility.

H14: Perceived feasibility influences entrepreneurial behavior.

For Ajzen (1991), personal attitude is the degree to which a person has a favorable or unfavorable assessment towards a given behavior, where such assessment depends on various factors like the positive or negative experiences that individual has had previously. In this case, such behavior refers to previous experience in business creation which is related to the individual's personal attitude towards entrepreneurship.

H15: Personal attitudes influence entrepreneurial behavior.
H16: Entrepreneurial behavior influences personal attitudes.

Also, personal attitudes influence the perceived convenience that potential entrepreneurs may have on the business creation process, this is explained by the positive attitude they develop as they accumulate more positive experiences throughout their personal experience (Hong et al., 2012; Moreno-Agudelo \& ValenciaArias, 2017; Torres et al., 2018).

H17. Personal attitudes influence perceived convenience.

H18: Perceived convenience influences personal attitudes.

According to Ajzen's theory of planned behavior (1991), the intention of the individual is based on the attitude towards the conduct, the subjective norm and the control of perceived behavior. Similarly, studies such as van Gelderen et al. (2008) and Liñán \& Chen (2009) suggest that attitude, subjective norm, and control of perceived behavior explain between 30\% $45 \%$ of the variability in the intentions.

H19: Personal attitudes influence entrepreneurial intention.

H20: Entrepreneurial intention influences personal attitudes.

Figure 2 shows the complete structure of the proposal for the Extension of the Systemic Entrepreneurship Intention Model, which was validated using an empirical study. Hypotheses taken from the previous model are written in gray, and the new ones are written in black.

In the proposed model the relationships between the constructs PA (Personal Attitudes) and RT (Risk Tolerance), the constructs PA (Personal Attitudes) and PF (Perceived Feasibility) and the constructs EB (Entrepreneurial Behavior) and RT (Tolerance Risk) have not been considered 


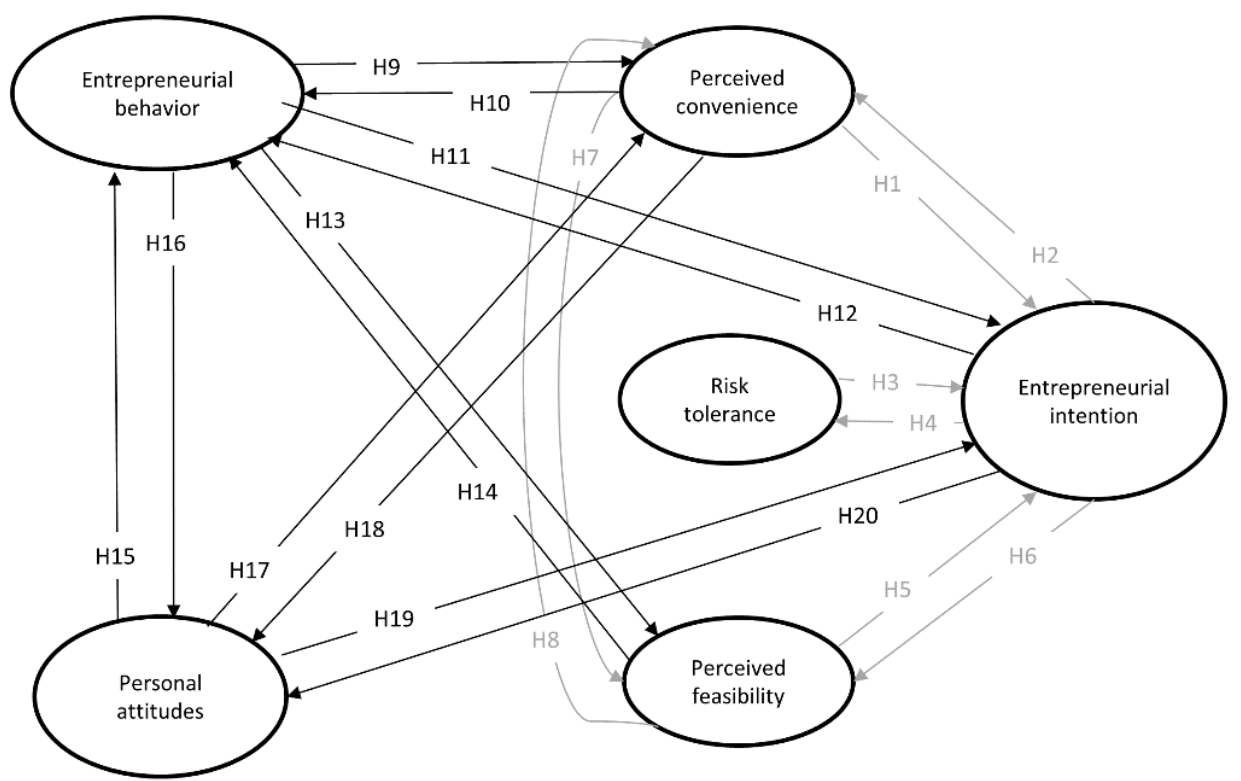

Figure 2. Hypothesis of the Extension of the Systemic Entrepreneurship Intention Model relation

because, in the literature review, no previous studies were identified that validated or considered these relationships relevant. Results section shows how weak these relationships are, consistent with the literature review.

\subsection{Data collection}

For this cross-cutting causal correlation, this study used a quantitative instrument (self-administered questionnaire) to gather information, which allows the validation of the model. This instrument used questions validated in previous studies as shown in Table 1.

A university population was selected since it is at this type of context that young people concentrate. This instrument was applied to 1290 active students at Instituto Tecnológico Metropolitano - ITM, Corporación Universitaria Minuto de Dios UNIMINUTO and Universidad de Medellín, in the city of Medellín. The sample was selected upon convenience criteria. A five- point Likert scale in which interviewees were asked to specify their degree of agreement or disagreement with each item was used to measure the factors proposed in the model. The information collected from each construct was validated using convergent discriminant processes (each one with its test statistics), then the final model was defined using Somers' D statistical, which measures the degree of association between different constructs.

\section{RESULTS}

The most important results will be presented according to the data collected. The first two parts of this section show the methods that validate the model, followed by the discussion and main implications in the developing countries context.

\subsection{Convergent Validity}

The validity of the measuring scales used, 
as well as that of the instrument and the constructs in general, were compared using confirmatory factor analysis with SPSS $®$ statistical software (IBM, 2016). In the first phase of the analysis, researchers were able to confirm that data collected during research did not seem to display redundant information as the factor loadings of the observable variables were higher than 0.5 (Bagozzi \& Yi, 1988), with an average above 0.7 (Hair et al., 2001). This way, the presence of convergent validity can be assured as shown in Table 2.

Bartlett's sphericity test and the KMO index are presented in Table 3. They are statistical items corresponding to the study of the sample's adaptation to the model. The first item is used to confirm the hypothesis that the obtained correlation matrix is an identity matrix; in other words, there are no significant intercorrelations between the variables that justify factor analysis (de la Fuente \& Justicia, 2003). Then, to be able to reject the null sphericity hypothesis, and consequently, to assure that the factor model is adequate to explain the data, the $\mathrm{P}$ value must be below the critical levels chosen
(Jiménez \& Manzano, 2005). Given the fact that this model presents Bartlett values equal to 0 , it can be stated that there are significant correlations between variables.

On the other hand, the appropriate sampling value of the measure, KaiserMeyer-Olkin (KMO) is an index that compares the magnitudes of the observed correlation coefficient with those of the partial correlation coefficient, and their values are between 0 and 1 . The higher the value, the better the factor adjustment; if values below 0.5 are obtained, they are considered unacceptable (Lévy et al, 2006).

As shown in Table 3, the coefficients obtained from the SPSS $($ software for each of the factors meet the previous criteria. This result indicates that it is feasible to conduct a data reduction technique, and this way analyzes the factors that influence university students' perceptions of creating enterprises.

\subsection{Discriminant Validity}

Discriminant validity is often used as the criteria to evaluate measuring scales of latent constructs in social sciences (Campbell \&

Table 1. General information of the information-gathering instrument.

\begin{tabular}{|c|c|c|}
\hline Construct & Question & Reference \\
\hline \multirow{2}{*}{$\begin{array}{l}\text { Personal } \\
\text { attitudes }\end{array}$} & Being an entrepreneur would be highly satisfying & (Liñan \& Chen, 2009) \\
\hline & Becoming an entrepreneur is appealing to me & (Liñán et al., 2013) \\
\hline \multirow{3}{*}{$\begin{array}{l}\text { Entrepreneurial } \\
\text { behavior }\end{array}$} & I can see market opportunities for new products and/or services & \multirow{3}{*}{ (Naktiyok et al., 2009) } \\
\hline & I can establish and maintain favorable relationships with potential investors & \\
\hline & I can come up with strategies to find market opportunities in my context & \\
\hline \multirow{2}{*}{$\begin{array}{l}\text { Entrepreneurial } \\
\text { intention }\end{array}$} & I will do everything I possibly can to create and manage my own company & \multirow[b]{2}{*}{ (Liñán et al., 2013) } \\
\hline & $\begin{array}{l}\text { I am determined to creating a new enterprise in the future } \\
\text { My professional objective is to be an entrepreneur }\end{array}$ & \\
\hline \multirow{2}{*}{ Risk tolerance } & Creating an enterprise is risky & \multirow{2}{*}{ (Segal et al., 2005) } \\
\hline & The option of starting a company is a potential opportunity I would fight for & \\
\hline \multirow[t]{2}{*}{$\begin{array}{l}\text { Perceived } \\
\text { convenience }\end{array}$} & $\begin{array}{l}\text { By creating a company, it is possible to improve the balance between work } \\
\text { and private life } \\
\text { An entrepreneur has a better lifestyle }\end{array}$ & \multirow[t]{2}{*}{ (Maes et al., 2014) } \\
\hline & Being an entrepreneur implies more advantages and disadvantages for me & \\
\hline \multirow{3}{*}{$\begin{array}{l}\text { Perceived } \\
\text { feasibility }\end{array}$} & Becoming or not an entrepreneur depends entirely on me & (Tkachev \& Kolvereid, 1999) \\
\hline & $\begin{array}{l}\text { If I tried to start a new company, it would have a very high probability of } \\
\text { success }\end{array}$ & (Liñán et al., 2013) \\
\hline & I am ready and capable of creating a new company & (Liñan \& Chen, 2009) \\
\hline
\end{tabular}


Table 2. Convergent validity of standardized factor loading

\begin{tabular}{lccc}
\hline \multicolumn{1}{c}{ Construct } & Item & $\begin{array}{c}\text { Standardized } \\
\text { factor loadings }\end{array}$ & $\begin{array}{c}\text { Average standardized factor } \\
\text { loadings }\end{array}$ \\
\hline Personal attitudes & PA1 & 0.880 & 0.880 \\
& PA2 & 0.880 & \\
Entrepreneurial behavior & EB1 & 0.732 & 0.753 \\
& EB2 & 0.777 & \\
Perceived convenience & EB3 & 0.750 & 0.813 \\
& PC1 & 0.780 & \\
Entrepreneurial intention & PC2 & 0.834 & 0.824 \\
& PC3 & 0.826 & \\
Risk tolerance & EI1 & 0.783 & 0.748 \\
EI2 & 0.830 & \\
Perceived feasibility & EI3 & 0.827 & 0.721 \\
& EI4 & 0.855 & \\
\hline
\end{tabular}

Table 3. Convergent validity of KMO and Bartlett's sphericity test

\begin{tabular}{lccc}
\hline Factor & KMO Value & Bartlett Value & Meets criteria \\
\hline Personal attitudes & 0.500 & 0,000 & Yes \\
Entrepreneurial behavior & 0.642 & 0,000 & Yes \\
Perceived convenience & 0.682 & 0,000 & Yes \\
Entrepreneurial intention & 0.738 & 0,000 & Yes \\
Risk tolerance & 0.500 & 0,000 & Yes \\
\hline
\end{tabular}

Fiske, 1959 cited in Martínez-García \& Martínez-Caro, 2009). In this research, a discriminant validity analysis was conducted by verifying that the confidence interval in the estimate of a correlation between each pair of factors did not have a value of 1 (Anderson \& Gerbing 1988). Table 4 evidences that all the cases meet said criteria. This result proves that the instrument used highly meets its measuring purposes.

The feasibility of the instrument's internal consistency was estimated using Cronbach's Alpha, as it is an instrument in which items (Likert-type scale) are assumed to measure the same construct and are highly correlated
(Welch \& Comer, 1988). If a Cronbach's Alpha value is close to 1 , the internal consistency of the items is higher, as the test reaches positive values ranging from 0 to 1 , where 0 indicates a total lack of internal consistency and 1 indicates the total redundancy between items.

George \& Mallery (2003) suggest the following scales to evaluate Cronbach's Alpha's coefficients: alpha coefficient $>0.9$ is excellent; alpha coefficient $>0.8$ is good; alpha coefficient $>0.7$ is acceptable; alpha coefficient $>0.6$ is questionable; alpha coefficient $>0.5$ is poor and alpha coefficient $<0.5$ is unacceptable. Nevertheless, in the 
Table 4. Discriminant validity of the measurement model

\begin{tabular}{lcccccc}
\cline { 2 - 6 } & PA & EB & PC & EI & RT & PF \\
\hline PA & & & & & & \\
EB & {$[0.381 ; 0.473]$} & & & & & \\
PC & {$[0.387 ; 0.484]$} & {$[0.431 ; 0.528]$} & & & & \\
EI & {$[0.537 ; 0.620]$} & {$[0.463 ; 0.554]$} & {$[0.505 ; 0.592]$} & & & \\
RT & {$[0.264 ; 0.366]$} & {$[0.224 ; 0.334]$} & {$[0.244 ; 0.346]$} & {$[0.316 ; 0.421]$} & & \\
PF & {$[0.351 ; 0.448]$} & {$[0.468 ; 0.557]$} & {$[0.427 ; 0.523]$} & {$[0.544 ; 0.626]$} & {$[0.245 ; 0.351]$} & \\
\hline
\end{tabular}

Headings are related to the construct's names.

starting phases of research, a feasibility value of 0.6 or 0.5 may be sufficient (Nunnally \& Bernstein, 1994).

As shown in Table 5, the measuring instrument has high feasibility of the measuring scale's internal consistency because the construct's Cronbach's Alpha of the analyzed constructs is found to be between the rank of values suggested by the previously mentioned authors and all the factors are higher than the recommended value.

Confirmatory analysis results evidence the existence of a sustainable factor model in university students' perceptions regarding the creation of enterprises. The instrument's convergent and discriminant validity, added

Table 5. Feasibility Index - Cronbach's Alpha

\begin{tabular}{lc}
\hline \multicolumn{1}{c}{ Factor } & $\begin{array}{c}\text { Cronbach's } \\
\text { Alpha }\end{array}$ \\
\hline Personal attitudes & 0.890 \\
Entrepreneurial behavior & 0.791 \\
Perceived convenience & 0.862 \\
Entrepreneurial intention & 0.899 \\
Risk tolerance & 0.723 \\
Perceived feasibility & 0.770 \\
\hline
\end{tabular}

to acceptable feasibility, ratified that it evaluates fundamental variables which affect university students' entrepreneurial ideas, expectations, and motivations.

\subsection{Analysis of the Results and Hypothesis Contrast}

To evaluate university students' entrepreneurial intentions, different hypotheses were proposed and evaluated, and the degree of association was measured using Somers' D statistical. This statistical corresponds to an association measurement between two ordinal variables with a value ranging from +1 to -1 , where extreme values mean perfect concordance or discordance, and the values close to 0 indicate a lack of association (Abascal \& Grande Esteban, 2005).

Table 6 shows Somers' D values obtained by the SPSS $\AA$ software for each construct. It is worth highlighting that the rows are dependent variables and the columns are independent. Also, the underlined values are those that are part of the hypotheses model. As such, only the relations that present strong concordance (with a value higher than 0.4) or a strong discordance (with a value lower than -0.4) are to be considered as key factors that effectively promote an entrepreneurial intention.

Out of the 20-hypothesis proposed, four did not obtain high values reflecting strong associativity (values are highlighted in bold print); therefore, they were discarded from the model. Thus, Figure 3 shows the proposed final model with its corresponding 
associativity values between the variables. It can be seen that all the significant constructs directly and positively influence an entrepreneurial intention, and at the same time, they directly and positively influence each construct. Additionally, there are positive relations between the other constructs which, when empowered, have a greater impact on an entrepreneurial intention.

\section{DISCUSSION}

In this study, we proposed an extension of the Systemic Entrepreneurship Intention
Model as it can represent in detail the items that encourage university students' entrepreneurial intention. We evaluated 20 hypotheses, and 4 of them were discarded given their low values (Somers' D below 0.4). All the relations between constructs (regardless of being part of the hypotheses model or not) have values above 2.4 , which evidences the existence of a positive dynamic between all of them (when one of them increases, the others increase as well).

It was found that the strongest relation corresponds to hypotheses 19, concerning the relation between personal attitudes and entrepreneurial intention, with a 0.588 Somers' D; this has also been corroborated

Table 6. Somers' D.

\begin{tabular}{ccccccc}
\cline { 2 - 7 } & PA & EB & PC & EI & RT & PF \\
\hline PA & 1,00 & $\mathbf{0 . 3 5 8}$ & $\mathbf{0 . 3 6 1}$ & 0.482 & 0.271 & 0.330 \\
EB & 0.422 & 1,00 & 0.429 & 0.447 & 0.251 & 0.457 \\
PC & 0.432 & 0.434 & 1,00 & 0.49 & 0.267 & 0.42 \\
EI & 0.588 & 0.463 & 0.501 & 1,00 & $\mathbf{0 . 3 5}$ & 0.529 \\
RT & 0.310 & 0.244 & 0.257 & $\mathbf{0 . 2 5 6}$ & 1,00 & 0.259 \\
PF & 0.396 & 0.465 & 0.424 & 0.529 & 0.270 & 1,00 \\
\hline
\end{tabular}

Headings are related to the construct's names.

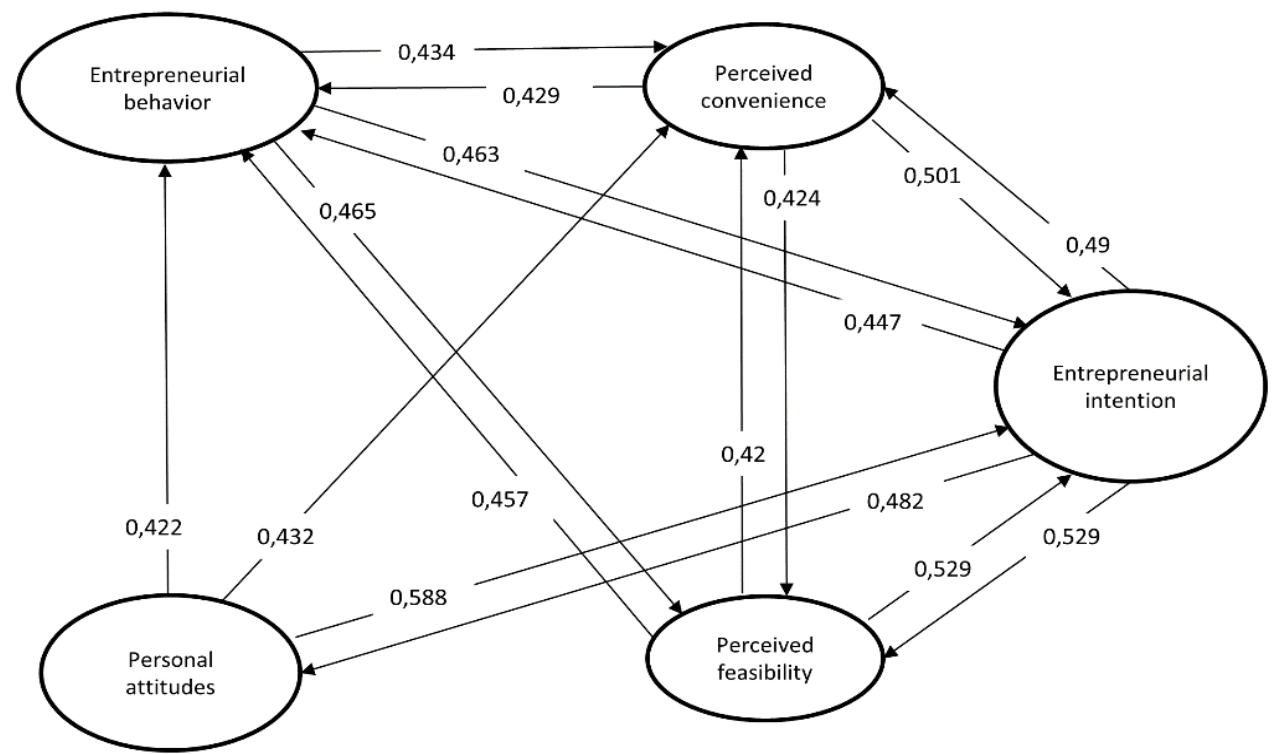

Figure 3. Extension of the Systemic Entrepreneurship Intention Model 
by different studies, including Peterman \& Kennedy (2003), Rae (2010) and Herrington et al., (2011). This relation is logical in this context because an educational environment strengthens positive attitudes towards entrepreneurship (Zeng et al., 2011; Mejía Ordoñez et al., 2017). Specifically, a high understanding of the creation of enterprises encourages entrepreneurship (Tshikovhi \& Shambare, 2015). Also, among personal attitudes associated with a higher probability of being an entrepreneur, factors such as creativity and innovative capacity seem to have the highest influence on encouraging entrepreneurship (Hattab, 2014; Jovanović et al., 2018). Therefore, it is recommended proposing pedagogic strategies that foster the creation of mechanisms aimed at strengthening university students' creative and innovative capacity.

The second strongest association corresponds to hypotheses 5 , concerning the relation between perceived feasibility and entrepreneurial intention, with a 0.529 Somers' D. The significant impact of perceived feasibility on entrepreneurial intention among university students is coherent with the findings proposed by (Solesvik et al., 2012; Dissanayake, 2013; Solesvik et al., 2014; Saadin \& Daskin, 2015). Also, it is a logical result because, in developing economies (such as Colombia), there is a strong influence of perceived feasibility on the intention to be an entrepreneur (Solesvik et al., 2014). It is interesting to notice that studies such as Hattab (2014) proposed that entrepreneurial education have no direct impact on improving students 'perceived feasibility; nevertheless, Armstrong (2014) proposes that university students' confidence and perceived feasibility can be reinforced through dynamic pedagogical strategies.
Thus, for future studies related to university contexts, it is highly advisable to consider the relation between entrepreneurial education and perceived feasibility as it is a decisive variable when creating enterprises.

Given the above, to effectively encourage entrepreneurial intention, it is advisable to consider strategies centered on changing personal attitudes and perceived feasibility, and then on theoretical knowledge, as their effects are more significant when those programs emphasize overcoming perceived barriers to fostering entrepreneurial initiatives (Raposo \& Do Paço, 2011). Also, it is highly recommended to promote different spaces, where the students can interact and make decisions to put into practice the knowledge acquired. This strategy will prevent multiple future errors in new businesses and generate more confidence. Also, it can be achieved through governmental and non-governmental support on consolidating new business ideas; and in academic contexts, it could be achieved through dynamic education and entrepreneurial practices in universities.

It was also found that relations associated to risk tolerance constructs were the weakest, which suggests that university students show higher intentions of creating enterprises when they identify good ideas and those ideas are feasible, with no consideration for risk levels. Therefore, this construct is removed from the model when its impact is not as strong as that of the others. This result is reasonable because a young student is often not as daring as an older adult, regarding stability, economic position, and family ties. On this matter, Dinis et al. (2013) found that the relation concerning risk tolerance did not report statistical significance in students. Furthermore, risk tolerance was found to be higher among 
university students from developed economies (which contradicts this case) as their possibilities of having stable jobs are also higher. Therefore, being an entrepreneur supposes higher economic and social risks (Iakovleva et al., 2011).

There is a strong relationship between entrepreneurial behavior and entrepreneurial intention. This finding could be because those surveyed are being trained as future professionals, which is represented in greater possibilities of support for the creation of companies, reflecting in more ambitious aims and visions than those of who do not receive training or support. Against this, it is highlighted the role of the economic and business environment as one of the influential factors in entrepreneurial intention, since these social, economic and cultural differences generate differences in the entrepreneurial behavior of individuals (Nikolić et al., 2019).

Similarly, it could be affirmed that exists high perceived probability on the part of individuals, that their attitudes can lead to a suitable creation of a company, which is coherent with the findings of Marques et al. (2012), who state that there is a positive relationship between attitude and intention with a high level of significance. Among the factors that can explain this attitude are the personal satisfaction generated by the entrepreneurial lifestyle because this style is associated with feelings of personal improvement, achievement and personal success (Marcketti et al., 2006; MontielCampos, 2018). These results are positive to the extent that a favorable personal attitude helps the individual to focus clearly on purpose to create a company since it feels attracted by this purpose (Moriano et al., 2011).

To achieve an effective increase in entrepreneurial intention, it is recommended that strategies be oriented more towards changing personal attitudes and controlling perceived behavior than towards theoretical knowledge since the effects are more significant when these programs emphasize overcoming perceived barriers to promoting entrepreneurship initiative (Raposo \& Do Paço, 2011). The above can be achieved through the support of different governmental and non-governmental entities in the face of the consolidation of new business ideas; and in the academic field, through dynamic education and entrepreneurial practices in university faculties.

Additionally, in view of the importance of entrepreneurial behavior, interesting findings have been reported in the literature, for example, a person with entrepreneurial skills will positively affect their subjective norms, favoring entrepreneurial behavior, and when an individual's social circle values and supports entrepreneurship more, it will feel that it has greater abilities to create a company, increasing its intention (Liñan \& Chen, 2009).

Although the constructs that had the strongest effect on entrepreneurial intention were identified, all the model's variables should be considered to take advantage of the dynamic of all the positive relations and to have a global perspective that encourages balanced leadership and helps manage calculated risk. The above causes that its result is represented by the value creation for a company, the economy, and society.

\section{CONCLUSIONS}

Based on the TPB and Valencia et al.'s Systemic Entrepreneurship Intention Model 
(2012), an extension of the Systemic Entrepreneurship Intention Model was conducted in this research. This model constitutes a detailed and decisive instrument for examining and identifying the factors and relations that motivate entrepreneurship in the academic field.

The theory of planned behavior, which not only positively or negatively evaluates an event in which an individual performs a behavior, but also considers social pressure to perform or not perform such behavior, helps visualize a clear a panorama that gathers a vast amount of information and presents adequate levels of association for each of the hypotheses that have been proposed.

The model can be explained as follows. When the degree of favorability of the constructs is increased (entrepreneurial behavior, personal attitudes, perceived convenience, and perceived feasibility), the probability of having students with a higher intention to incorporate and consolidate also increases. Therefore, when association margins between related constructs are adequate, it is correct to say that the model fulfills the objectives proposed in this research. In this study, the existence of relations with significant levels of association is evidenced. Therefore, the model allows examining how external variables affect the decision of creating a business.

The purpose of this paper was related to the identification of factors to influence the entrepreneur intention in university students, how these factors interact, and which strategies can have the greatest impact on the intention to turn into action. In this sense, the factors with the highest association values are personal attitudes and perceived feasibility, so it is recommended that these strategies focus on increasing the feasibility of business ideas by providing students with entrepreneurial skills through governmental support. Strategies concerning perceived feasibility help increasing entrepreneurial intention, and strategies concerning personal attitudes help keep them alive once they have been created.

It is also important to acknowledge that since no discordance was observed between the constructs, and given the multiple relations found between them, it is necessary to consider reinforcement dynamics; when one of the constructs is incentivized, it provides the others with feedback. The above means that if long-term strategies are implemented, there will be noticeable increases in entrepreneurial intention.

In this sense, the importance of generating spaces for university students to encourage their entrepreneurial intention is highlighted, beyond the theoretical knowledge this population must identify the benefits and positive elements of starting a business. A clear example of this is the design of cocreation rooms, with the participation of students and entrepreneurs where the exchange of ideas and experiences is encouraged, allowing the development the creativity in the students. Therefore, our research provides practical implications for the design of strategies in universities and the design of public policies for entrepreneurship in university students. As a fundamental practical contribution the mechanisms that should be implemented in developing economies highlight where it is important that students can have experiences of business creation (cases successful) that really contribute to the development of these economies and are aligned with the economic sectors of those countries (many studies have been carried out in developed 
economies). Finally, it is important to mention as a practical contribution to the non-existence of risk tolerance to start a business by the university students, this meaning a propitious scenario to encourage the creation of business.

As for future research, this study recommends the validation of this model in other higher education institutes from emerging economies to contribute to the strengthening of strategies that empower young people's entrepreneurial intentions. Moreover, it is interesting to observe how the inclusion of other external variables can precisely explain young people's entrepreneurial intention and help propose more effective strategies. Therefore, it seems advisable to consider perceived self-efficacy as a mediating factor between tolerance and entrepreneurial intention. Finally, some of the limitations of the proposed model include the fact that it relies on a cross-cutting design. Conducting a longitudinal study would identifying the validity of the factors identified as well as the effectiveness of the proposed scenarios and strategies in such a way that it could increase the success in the entrepreneurial intention of this population.

\section{References}

Abascal, E., \& Grande Esteban, I. (2005). Survey Analysis. Madrid, ES: ESIC Editorial, Ed. (in Spanish)

Ajzen, I. (1991). The theory of planned behavior. Orgnizational Behavior and Human Decision Processes, 50, 179-211.

\section{ПРОШИРЕЊЕ МОДЕЛА СИСТЕМСКОГ ПРИСТУПА ПРЕДУЗЕТНИШТВУ КОД УНИВЕРЗИТЕТСКИХ СТУДЕНАТА}

\section{Luisa Díez-Echavarría, Alejandro Valencia Arias, Fausto Orlando Maussa Pérez, Maria Lucelly Urrego Marín, Jairo Adolfo Torres Velásquez}

\section{Извод}

Предлаже се проширење модела системског приступа предузетништву, како би се идентификовали и разумели фактори, као и њихови односи, који промовишу предузетничке намере студената. То је, дугорочно гледано, једна од главних стратегија за промоцију економског развоја. Коришћена је факторска анализа како би се анализирали подаци прикупљени кроз упитник који је примењен код студената три универзитета у Колумбији. Утврђено је да су лични ставови и пертиципирана изводљивост најутицајнији фактори када је у питању покретање посла. Штавише, млади људи могу имати више изражене намере да створе компанију, уколико идентификују добре идеје и схвате их изводљивим, без обзира на ниво ризика. Препоручује се примена овог модела у контексту студената универзитета у економијама у развоју како би се добили поуздани резултати у разумевању њиховог понашања.

Кључне речи: предузетничка намера, високо образовање, студентска популација, теорија планираног понашања. 
Ajzen, I., \& Fishbein, M. (1980). Understanding attitudes and predicting social behavior. Behavior and Human Decision Processes, 50 (2), 179-211.

Anderson, J.C., \& Gerbing, D.W. (1988). Structural equation modeling in practice: A review and recommended two-step approach. Psychological Bulletin, 103 (3), 411-423.

Armitage, C.J., \& Conner, M. (2001). Efficacy of the Theory of Planned Behaviour: a meta-analytic review. The British Journal of Social Psychology, 40 (Pt 4), 471-499.

Armstrong, C.E. (2014). I meant to do that! Manipulating entrepreneurial intentions through the power of simple plans. Journal of Small Business and Enterprise Development, 21 (4), 638-652.

Audet, J. (2004). A Longitudinal Study of the Entrepreneurial Intentions of University Students. Academy of Entrepreneurship Journal, 10 (1), 3-16.

Awogbenle, A.C., \& Iwuamadi, K.C. (2010). Youth unemployment: Entrepreneurship development programme as an intervention mechanism. African Journal of Business Management, 4 (6), 831-835.

Bagozzi, R.P., \& Yi, Y. (1988). On the evaluation of structural equation models. Journal of the Academy of Marketing Science, 16 (1), 74-94.

Benyamin, L. (2016). Emergence and Emergents in Entrepreneurship: Complexity Science Insights into New Venture Creation. Entrepreneurship Research Journal, 6 (1), 43-52.

Botsaris, C.A., \& Vamvaka, V. (2012). Models of the determinants of entrepreneurial behaviour: a literature review. Regional Science Inquiry Journal, IV (3), 155-172.
Cadavid, L., Díez-Echavarría, L., \& Valencia, A. (2017). Spin-off activities at higher educational institutions: Performance implications from a modeling perspective. Journal of Developmental Entrepreneurship, 22 (02), 1-21.

Carey, T., Flanagan, D., \& Palmer, T. (2010). An examination of university student entrepreneurial intentions by type of venture. Journal of Developmental Entrepreneurship, 15 (04), 503-517.

Cassar, G. (2007). Money, money, money? A longitudinal investigation of entrepreneur career reasons, growth preferences and achieved growth. Entrepreneurship and Regional Development, 19 (1), 89-107.

De la Fuente, J., \& Justicia, F. (2003). ACRA-Abbreviated learning strategies scale for university students. Electronic Journal of Research in Educational Psychology, 1 (2), 139-158. (in Spanish)

Devonish, D., Alleyne, P., CharlesSoverall, W., Marshall, A., \& Pounder, P. (2010). Explaining Entrepreneurial Intentions in the Caribbean. International Journal of Entrepreneurial Behaviour \& Research, 16 (2), 149-171.

Díaz-Casero, J.C., Ferreira, J.J.M., Mogollón, R.H., \& Raposo, M.L.B. (2012). Influence of institutional environment on entrepreneurial intention: a comparative study of two countries university students. International Entrepreneurship and Management Journal, 8(1), 55-74.

Dinis, A., do Paço, A., Ferreira, J., Raposo, M., \& Gouveia Rodrigues, R. (2013). Psychological characteristics and entrepreneurial intentions among secondary students. Education + Training, 55 (8/9), 763-780.

Dissanayake, D.M. (2013). The impact of perceived desirability and perceived 
feasibility on entrepreneurial intention among undergraduate students in Sri Lanka: An Extended Model. The Kelaniya Journal of Managemen, 2 (1), 39-57.

Echeverri-Sánchez, L., Valencia-Arias, A., Benjumea-Arias, M., \& Barrera-Del Toro, A. (2018). Factors That Affect the Entrepreneurial Intention in University Students: A Qualitative Analysis. Revista Electrónica Educare, 22 (2), 1-19. (in Spanish)

Echeverri, D., Cadavid, L., \& Awad, G. (2012). Intention and entrepreneurial conduct, an approximation from the neuronal networks. (pp. 2994-3005). Rio de Janeiro: Congreso Latino-Iberoamericano de Investigación Operativa. (in Spanish)

Erikson, T. (2002). Entrepreneurial capital: the emerging venture's most important asset and competitive advantage. Journal of Business Venturing, 17 (3), 275-290.

Fayolle, A., \& Gailly, B. (2015). The impact of entrepreneurship education on entrepreneurial attitudes and intention: Hysteresis and persistence. Journal of Small Business Management, 53 (1), 75-93.

Ferreira, J.J., Raposo, M.L., Rodrigues, R.G., Dinis, A., \& do Paço, A. (2012). A model of entrepreneurial intention: An application of the psychological and behavioral approaches. Journal of Small Business and Enterprise Development, 19 (3), 424-440.

George, D., \& Mallery, P. (2003). SPSS for Windows step by step: a simple guide and reference (4th ed.). Boston: Allyn \& Bacon.

Ghazali, Z., Ibrahim, N. A., \& Zainol, F.A. (2012). Factors affecting entrepreneurial intention among UniSZA students. Asian Social Science, 9 (1), 85-93.

Hair, J.F., Anderson, R.E., Tatham, R.L., \& Black, W.C. (2001). Multivariate analysis (5th ed.). Madrid: Prentice Hall Iberia. (in Spanish).

Hattab, H.W. (2014). Impact of entrepreneurship education on entrepreneurial intentions of university students in Egypt. Journal of Entrepreneurship, 23 (1), 1-18.

Hernández-López, D.M., Moncada-Toro, J.F., \& Henao-Colorado, L.C. (2018). Entrepreneurial intention of employees in the private sector in Medellín andits metropolitan area, 4 (7), 13-33. (in Spanish).

Herrington, M, Kew, J, Simre, M \& Turton, N. (2011). Global Entrepreneurship Monitor South Africa. Cape Town, South Africa: University of Cape Town Centre for Innovation and Entrepreneurship.

Hess, L., Petersen, A., \& Mortimer, J. (2006). Youth, unemployment and marginality: The problem and solution. In A. C. Petersen \& J. T. Mortimer (Eds.), Youth unemployment and society (pp. 3-33). Cambridge University Press.

Hong, Z., Hong, T., Cui, Z., \& Luzhuang, W. (2012). Entrepreneurship quality of college students related to entrepreneurial education: Empirical study on psychological and behavioral characteristics. Energy Procedia, 17, 1907-1913.

Iakovleva, T., Kolvereid, L., \& Stephan, U. (2011). Entrepreneurial intentions in developing and developed countries. Education and Training, 53 (5), 353-370.

Jiménez, E.U., \& Manzano, J.A. (2005). Applied Multivariate Analysis: ThomsonParaninfo. (in Spanish)

Jovanović, I., Arsić, M., \& Nikolić, Đ. (2018). Entrepreneurial personality traits and SMEs profitability in transition economy. Serbian Journal of Management, 13 (1), 89-104.

Kautonen, T., Gelderen, M., \& Fink, M. (2015a). Robustness of the theory of planned 
behavior in predicting entrepreneurial intentions and actions. Entrepreneurship Theory and Practice, 39 (3), 655-674.

Kautonen, T., Hatak, I., Kibler, E., \& Wainwright, T. (2015b). Emergence of entrepreneurial behaviour: The role of agebased self-image. Journal of Economic Psychology, 50, 41-51.

Kautonen, T., van Gelderen, M., \& Tornikoski, E. T. (2013). Predicting entrepreneurial behaviour: a test of the theory of planned behaviour. Applied Economics, 45 (6), 697-707.

Kim $\neg$ Soon, N., Rahman, A., \& Nadia, N. (2014). Entrepreneurial Motivation and Entrepreneurship Career Intention: Case at a Malaysian Public University. In International Business Information Management Association (IBIMA) (pp. 1-1). Milan, Italy.

Küttim, M., Kallaste, M., Venesaar, U., \& Kiis, A. (2014). Entrepreneurship education at university level and students' entrepreneurial intentions. Procedia - Social and Behavioral Sciences, 110, 658-668.

Lee, L., Wong, P.K., Foo, M. Der, \& Leung, A. (2011). Entrepreneurial intentions: The influence of organizational and individual factors. Journal of Business Venturing, 26 (1), 124-136.

Lévy, J. P., Martín, M. T., \& Román, M. V. (2006). Optimization according to covariance structures. in J. Lévy \& J. Varela, Eds., Modeling with covariance structures in social sciences (in Spanish).

Liñan, F., \& Chen, Y. W. (2009). Development and cross-cultural application of a specific instrument to measure entrepreneurial intentions. Entrepreneurship Theory and Practice, 33 (3), 593-617.

Liñán, F., \& Fayolle, A. (2015). A systematic literature review on entrepreneurial intentions: citation, thematic analyses, and research agenda. International
Entrepreneurship and Management Journal, 11 (4), 907-933.

Liñán, F., Rodríguez-Cohard, J. C., \& Guzmán, J. (2011). Temporal stability of entrepreneurial intentions: a longitudinal study. Pp. 34-55 in O. Borch, A. Fayolle, P. Kyrö \& E. Ljunggren (Eds), Entrepreneurship Research in Europe: Evolving Concepts and Processes. UK, Edward Elgar Publishing Limited.

Liñán, F., Rodríguez-Cohard, J.C., \& Guzmán, J. (2011). Temporal stability of entrepreneurial intentions: a longitudinal study. In Entrepreneurship Research in Europe: Evolving Concepts and Processes (p. 22).

Lortie, J., \& Castogiovanni, G. (2015). The theory of planned behavior in entrepreneurship research: what we know and future directions. International Entrepreneurship and Management Journal, 11 (4), 935-957.

Machin, S., \& Manning, A. (1999). The Causes and Consequences of Long-Term Unemployment in Europe. Pp. 3085-3139 in O. Ashenfelter \& D. Card (Eds), Handbook of Labor Economics, Vol. 3. UK, North Holland.

Maes, J., Leroy, H., \& Sels, L. (2014). Gender differences in entrepreneurial intentions: A TPB multi-group analysis at factor and indicator level. European Management Journal, 32 (5), 784-794.

Marcketti, S. B., Niehm, L. S., \& Fuloria, R. (2006). An Exploratory Study of Lifestyle Entrepreneurship and Its Relationship to Life Quality. Family and Consumer Sciences Research Journal, 34(3), 241-259.

Marques, C.S., Ferreira, J.J., Gomes, D.N., \& Gouveia Rodrigues, R. (2012). Entrepreneurship education. Education and Training, 54 (8/9), 657-672.

Martin, B.C., McNally, J.J., \& Kay, M.J. 
(2013). Examining the formation of human capital in entrepreneurship: A meta-analysis of entrepreneurship education outcomes. Journal of Business Venturing, 28 (2), 211-224.

Martínez-García, J., \& Martínez-Caro, L. (2009). Discriminant validity as an evaluation criterion of scales: theory or statistics? Universitas Psychologica, 8 (1), 27-36. (in Spanish).

Marulanda, F.Á., Montoya, I.A., \& Vélez, J.M. (2014). Motivational theories in the study of entrepreneurship. Pensamiento \& Gestión, 36, 204-236. (in Spanish)

Mejía Ordoñez, J.P., Arias Marín, C.M., \& Echeverri Sánchez, L.C. (2017). Role of entrepreneurship education in the university context from studies registered in Scopus. Revista CEA, 3 (5), 69-87. (in Spanish)

Mohamed, Z., Rezai, G., Nasir Shamsudin, M., \& Mu'az Mahmud, M. (2012). Enhancing young graduates' intention towards entrepreneurship development in Malaysia. Education and Training, 54 (7), 605-618.

Montiel-Campos, H. (2018). The entrepreneurial passion-entrepreneurial alertness relationship: The moderating role of a creative personality. Serbian Journal of Management, 13 (2), 263-280.

Montoya, I., Valencia, A., \& Montoya, A. (2016). Field mapping of knowledge in entrepreneurial intentions through analysis of social knowledge network. Ingeniare. Revista Chilena de Ingeniería, 24 (2), 337-350. (in Spanish)

Moreno-Agudelo, J. A., \& ValenciaArias, J. A. (2017). F Factors involved in the adoption of free software by SMEs in Medellín. Revista CEA, 3 (6), 55-75. (in Spanish).

Moriano, J.A., Gorgievski, M., Laguna, M., Stephan, U., \& Zarafshani, K. (2011). A cross-cultural approach to understanding entrepreneurial intention. Journal of career development, 39 (2), 162-185.

Murugesan, R., \& Dominic, P.D.D. (2013). Influencing entrepreneurial intentions: the role of attitudes and personality constructs. International Journal of Business Excellence, 6 (6), 687-701.

Naktiyok, A., Karabey, N.C., \& Gulluce, A.C. (2010). Entrepreneurial self-efficacy and entrepreneurial intention: the Turkish case. International Entrepreneurship Management Journal, 6 (4), 419-435.

Naktiyok, A., Nur Karabey, C., \& Caglar Gulluce, A. (2009). Entrepreneurial selfefficacy and entrepreneurial intention: the Turkish case. International Entrepreneurship and Management Journal, 6 (4), 419-435.

Nasiru, A., Keat, O.Y., \& Bhatti, M.A. (2015). Influence of perceived university support, perceived effective entrepreneurship education, perceived creativity disposition, entrepreneurial passion for inventing and founding on entrepreneurial intention. Mediterranean Journal of Social Sciences, 6 (3), 88-95.

Ng, K.S., Ahmad, A.R., \& Ibrahim, N.N. (2014). Entrepreneurial motivation and entrepreneurship career intention: case at a Malaysian Public University. In 24th International Business Information Management Association (pp. 1001-1011). Milan.

Nikolić, N., Jovanović, I., Nikolić, Đ., Mihajlović, I., \& Schulte, P. (2019). Investigation of the Factors Influencing SME Failure as a Function of Its Prevention and Fast Recovery after Failure. Entrepreneurship Research Journal, 9 (3), 121.

Nunnally, J. C., \& Bernstein, I. H. (1994). Psychometric theory. New York, USA: McGraw-Hill. 
Obschonka, M., Goethner, M., Silbereisen, R.K., \& Cantner, U. (2012). Social identity and the transition to entrepreneurship: The role of group identification with workplace peers. Journal of Vocational Behavior, 80 (1), 137-147.

Olsen, M. A. K. (2013). Exploring Faculty Members' Perceptions of Undergraduate Entrepreneurship Education: George Mason University.

Ortiz-Delgadillo, G., Esquivel-Aguilar, E.O., \& Hernández-Castorena, O. (2017). The Impact of customer relationship and the ability to value-added service in the performance of manufacturing SMEs in Aguascalientes. Revista CEA, 2 (4), $47-58$. (in Spanish)

Peterman, N.E., \& Kennedy, J. (2003). Enterprise Education: Influencing Students' Perceptions of Entrepreneurship. Entrepreneurship Theory and Practice, 28 (2), 129-144.

Quiroga-Juárez, C.A., \& VillalobosEscobedo, A. (2015). Analysis of stock market behavior of the major financial exchanges worldwide using multivariate analysis (principal component analysis PCA) for the period 2011 to 2014. Revista CEA, 1 (2), 25-36.

Rae, D. (2010). Universities and enterprise education: responding to the challenges of the new era. Journal of Small Business and Enterprise Development, 17(4), 591-606.

Raposo, M., \& Do Paço, A. (2011). Entrepreneurship education: Relationship between education and entrepreneurial activity. Psicothema, 23 (3), 453-457.

Saadin, M.N., \& Daskin, M. (2015). Perceived desirability, feasibility, and social norms as antecedents on hospitality students' entrepreneurial intention in Malaysia: does gender make a difference? International
Journal of Entrepreneurship and Small Business, 25(4), 456-474.

Sampedro, I.R., Fernández-Laviada, A., \& Crespo, Á.H. (2013). Applying the Theory of Reasoned Action to Entrepreneurship within a University Setting, 26, 141-158. (in Spanish)

Sánchez, J.C. (2010). University training for entrepreneurial competencies: Its impact on intention of venture creation. International Entrepreneurship and Management Journal, 7 (2), 239-254.

Sánchez, J.C., Lanero, A., \& Yurrebaso, A. (2005). Determinant Variables of the Entrepreneurial Intention in the University Context. Revista de Psicología Social Aplicada, 15, 37-60. (in Spanish)

Segal, G., Borgia, D., \& Schoenfeld, J. (2005). The motivation to become an entrepreneur. International Journal of Entrepreneurial Behavior \& Research, 11 (1), 42-57.

Setiawan, J. L. (2012). Entrepreneurship Program Assessment by Students Outcome on Their Perceived Entrepreneurial Characteristics. In Proceedings of the 4th Indonesia International Conference on Innovation, Entrepreneurship \& Small Business (pp. 1-6).

Solesvik, M., Westhead, P., \& Matlay, H. (2014). Cultural factors and entrepreneurial intention: The role of entrepreneurship education. Education+Training, 56 (8/9), 680-696.

Solesvik, M. Z., Westhead, P., Kolvereid, L., \& Matlay, H. (2012). Student intentions to become self-employed: the Ukrainian context. Journal of Small Business and Enterprise Development, 19 (3), 441-460.

Tkachev, A., \& Kolvereid, L. (1999). Selfemployment among Russian students. Entrepreneurship and Regional Development, 11 (3), 269-280. 
Torres, J.A., Valencia, A., Bermúdez, J., Díez-Echavarría, L.F., Urrego, M.L., \& Maussa, F.O. (2018). Characterization of entrepreneurial intention in university students as from Systemic Entrepreneurship Intention Model: a case study. Cuadernos de Gestión, 18 (2), 95-114.

Tshikovhi, N., \& Shambare, R. (2015). Entrepreneurial knowledge, personal attitudes, and entrepreneurship intentions among South African Enactus students. Problems and Perspectives in Management, 13 (1), 152-158.

Valencia-Arias, A., Gutiérrez Flórez, L., Montoya Restrepo, L. A., Umba López, A. Ma., \& Montoya Restrepo, I. (2017). Considerations about entrepreneurship strategic as functional synthesis of the opportunity identification and creation of competitive advantages. Revista Virtual Universidad Católica Del Norte, (52), 143-159. (in Spanish)

Valencia, A., \& Benjumea, M. (2013). A view of the enterprise from systemic archetypes. Sinapsis, 5 (5), 105-113. (in Spanish)

Valencia, A., Cadavid, L., Ríos, D. C., \& Awad, G. (2012). Factors influencing the Entrepreneurial

Intentions of Students. Revista Venezolana de Gerencia, 17 (57), 132-148. (in Spanish)

Valencia, J., Macias, J., \& Valencia, A. (2015). Formative Research in Higher Education: Some Reflections. Procedia Social and Behavioral Sciences, 176, 940-945.

van Dam, K., Schipper, M., \& Runhaar, P. (2010). Developing a competency-based framework for teachers' entrepreneurial behaviour. Teaching and Teacher Education, 26( 4), 965-971.

van Gelderen, M., Brand, M., van Praag,
M., Bodewes, W., Poutsma, E., \& van Gils, A. (2008). Explaining entrepreneurial intentions by means of the theory of planned behaviour. Career Development International, 13 (6), 538-559.

Van Gelderen, M., Kautonen, T., \& Fink, M. (2015). From entrepreneurial intentions to actions: Self-control and action-related doubt, fear, and aversion. Journal of Business Venturing, 30 (5), 655-673.

Welch, S., \& Comer, J. (1988). Quantitative methods for public administration: Techniques and applications. USA: The Dorsey Press.

Zeng, F.Q., Bu, X.Z., \& Su, L. (2011). Study on entrepreneurial process model for SIFE student team based on Timmons model. Journal of Chinese Entrepreneurship, 3 (3), 204-214.

Zhao, H., Seibert, S.E., \& Hills, G.E. (2005). The Mediating Role of Self-Efficacy in the Development of Entrepreneurial Intentions. Journal of Applied Psychology, 90 (6), 1265-1272. 